\title{
First report of L1014F-kdr mutation in Culex pipiens complex from Morocco
}

\author{
Meriem Bkhache ${ }^{1,2}$, Fatim-Zohra Tmimi ${ }^{1}$, Omar Charafeddine ${ }^{2}$, Chafika Faraj ${ }^{3}$, Anna-Bella Failloux ${ }^{4}$ and \\ M'hammed Sarih $^{1 *}$
}

\begin{abstract}
Background: Mosquitoes of the Culex pipiens complex, competent vectors for West Nile virus (WNV) and Rift Valley fever virus (RVFV) are widely targeted by insecticide treatments. The intensive application of chemical insecticides led to the development of resistance in many insects including Culex pipiens mosquitoes. The absence of data on resistance mechanisms in Morocco allow us to assess the levels of lambda-cyhalothrin resistance and the frequency of the mutated gene L1014F kdr in different forms of $C$ x. pipiens complex from three regions of Morocco.
\end{abstract}

Methods: Mosquito adults were reared from immature stages collected in three different regions in Morocco (Tangier, Casablanca and Marrakech). Standard WHO insecticide susceptibility tests were conducted on adults emerged from collected larvae. Specimens were identified as belonging to the Culex pipiens complex using a multiplex PCR assay with diagnostic primers designed from the flanking region of microsatellite CQ11. Identified mosquitoes were then tested for the presence of the L1014F kdr mutation using PCR assay.

Results: Our results showed that $21 \%$ of the tested population has a resistance to lambda-cyhalothrin. The molecular identification of survivors shows that $43 \%$ belonged to the $C X$. pipiens pipiens and only $9.5 \%$ to the $C X$. pipiens molestus form. On the other hand, 416 specimens were screened for the L1014F kdr mutation. L1014F mutation was detected in different forms of $C$ x. pipiens in different sites. The frequency of L1014F mutation was similar between the $C x$. pipiens pipiens form and hybrid form, while it was lower in the CX. pipiens molestus form. The presence of the $\mathrm{L} 1014 \mathrm{~F} k d r$ allele was significantly associated with resistance to lambda-cyhalothrin in $C X$. pipiens pipiens $(P<0.0001)$ and hybrid form $(P<0.0001)$.

Conclusion: Resistance to lambda-cyhalothrin of $C$. pipiens populations appears to be largely due to the L1014F $k d r$ mutation. To our knowledge, the frequencies of L1014F kdr mutation are examined for the first time in natural populations of the Culex pipiens complex in Morocco. These findings will provide important information to propose more adapted vector control measures towards this mosquito species, potential vector of arboviruses.

Keywords: Culex pipiens, L1014F kdr, Lambda-cyhalothrin, Resistance, Morocco

\section{Background}

Mosquitoes of the Culex pipiens complex are potential vectors of Rift Valley fever virus (RVFV) and West Nile virus (WNV). RVFV is a Phlebovirus of the family Bunyaviridae, considered as an emerging zoonotic vector-borne disease representing a threat to animal and human health, and livestock production mainly in subSaharan Africa [1]. It causes abortions and high

\footnotetext{
*Correspondence: mhammed.sarih@pasteur.ma

'Institut Pasteur du Maroc, Laboratoire des Maladies Vectorielles, Place Louis

Pasteur, Casablanca 20360, Morocco

Full list of author information is available at the end of the article
}

mortalities in newborn animals [2,3], and in humans, it gives different symptoms varying from a flu-like syndrome to hemorrhagic manifestations with a case fatality rates as high as 50\% [4]. Besides, WNV is an arbovirus of the family Flaviviridae and the genus Flavivirus. It has an extensive distribution throughout Africa, the Middle East, southern Europe, western Russia, southwestern Asia and Australia.

Widely spread in North Africa, Culex pipiens complex is a competent vector of several pathogens affecting human and/or animals such as WNV [5] and RVFV [6]. In Morocco, Culex pipiens mosquitoes have been strongly 
suspected as being the vectors of WNV during epizootics in 1996 with 42 dead horses [7-9] and in 2003 [10]. In the Maghreb region, WNV was repeatedly responsible for several outbreaks: Algeria (1994), Tunisia (1997, 2003, 2010-2012), and Morocco (1996, 2003 and 2010) [10-12].

Culex pipiens includes two forms, pipiens and molestus, which are morphologically identical but genetically different. They are also distinguishable by their physiological and behavior differences. Pipiens form is anautogenous (needs a blood meal for eggs development), ornithophilic (feeds on birds), heterodynamic (enters into diapause in winter), and eurygamous (prefers mating in large and open spaces), whereas molestus form is autogenous (lays the first egg batches without feeding on blood), mammophylic (feeds on mammals), homodynamic (is active throughout the year), and stenogamous (mates in closed areas) [13]. In the absence of effective vaccines, the control of mosquito populations remains the unique measure to limit pathogen transmission. Thus, the use of insecticides plays a major role in the prevention and control of vector-borne diseases. However, the frequent use of insecticides (mainly pyrethroids and organophosphates) has contributed to select several resistance mechanisms in targeted mosquito populations. There are two mechanisms of resistance: (i) increased production of detoxifying enzymes such as cytochrome P450 oxidases or glutathione-S-transferases; and (ii) modification of insecticides targets as the synaptic acetylcholinesterase (AchE1) encoded by ace-1 gene, the $\gamma$-aminobutyric acid (GABA) receptor gene encoded by $R d l$ and the voltage-dependant sodium channel encoded by $k d r[14,15]$. Pyrethroids (PYR) target Sodium channels; this neurotoxin insecticide binds to the $\mathrm{Na}+$ channel and then prolongs depolarization [16-18]. The magnitude of the PYR effect depends on the type of insecticide molecule: the type I insecticide (e.g. permethrin) does not present a cyano group compared to the type II insecticide (e.g. lambda-cyalothrin and delmathrin). The type II insecticides induce a more acute effect as they produce longer depolarization [17]. Phenotypically, $\mathrm{Na}+$ channels inactivation results in a rapid knockdown $(k d)$ of mosquitoes leading in some cases to death. Resistance to $k d$ is caused by a mutation L1014F, the substitution of a leucine at position 1,014 by a phenylalanine conferring the $k d r$ phenotype [19], leading to a lower sensitivity of receptors to these insecticides and modifying the potential action of the channel $[18,20]$.

In Morocco, the mechanisms responsible for insecticide resistance in $C x$. pipiens remain unknown; the only data available describes the level of larval resistance to the OP insecticide temephos [21]. Knowing that insecticide resistance remains a global issue for the control of mosquito-borne diseases, this study aims to investigate the L1014F $k d r$ mutation frequencies in different forms of Culex pipiens complex collected in three regions in Morocco: Tangier, Casablanca and Marrakech.

\section{Methods \\ Collection sites}

Mosquitoes were collected as larvae using the "dipping" sampling method during summer 2015 from three Moroccan regions (Fig. 1). Sampling was carried out in three bioclimatic zones: humid (Tangier), semi-arid (Casablanca) and arid (Marrakech). In each region, we have selected two sites: an urban site (in the center of the city) and a rural site (either in villages or in the city outskirts where inhabitants live at close proximity with planted areas and domestic animals). Fourth instar larvae were used for morphological identification and reared until imago stage at $28 \pm 1{ }^{\circ} \mathrm{C}$ with $80 \%$ relative humidity and a $16 \mathrm{~h}: 8 \mathrm{~h}$ photoperiod. Mosquitoes were identified as Culex pipiens using a dichotomous key for the identification of the Culicidae in the Mediterranean area [22].

\section{Insecticide susceptibility test}

Adult bioassays were conducted using four batches of 20 25 females. One-three day-old unfed females were exposed for $1 \mathrm{~h}$ to insecticide-impregnated $0.05 \%$ lambdacyhalothrin according to World Health Organization (WHO) recommendations. As a control, 50 non-bloodfed females mosquitoes were exposed to insecticide-free papers. The number of mosquitoes knocked down while were exposed to insecticide was recorded at intervals of $10 \mathrm{~min}$, and then the percentage of mortality was calculated at $24 \mathrm{~h}$ post-exposure. Dead and surviving mosquitoes were conserved at $-20{ }^{\circ} \mathrm{C}$ for molecular species identification and $k d r$ analysis.

\section{Identification of Culex pipiens forms}

DNA was extracted individually from mosquitoes using the method of DNAzol as described in the manufacturer's protocol. Specimens were identified as Culex pipiens complex using a multiplex PCR assay described in Bahnck \& Fonseca [23]. The locus CQ11 was used to distinguish between the forms of $C x$. pipiens: pipiens, molestus and hybrid.

\section{Detection of $K d r$ mutation}

For the detection of $k d r$ mutation, two separate PCRs were run, one to detect alleles of the leucinephenylalanine substitution and the other to detect wild-type susceptible alleles following the methods described in Martinez-Torres et al. [24]. DNA fragments were separated by electrophoresis on $1.5 \%$ agarose gel with ethidium bromide and viewed under ultraviolet light. 


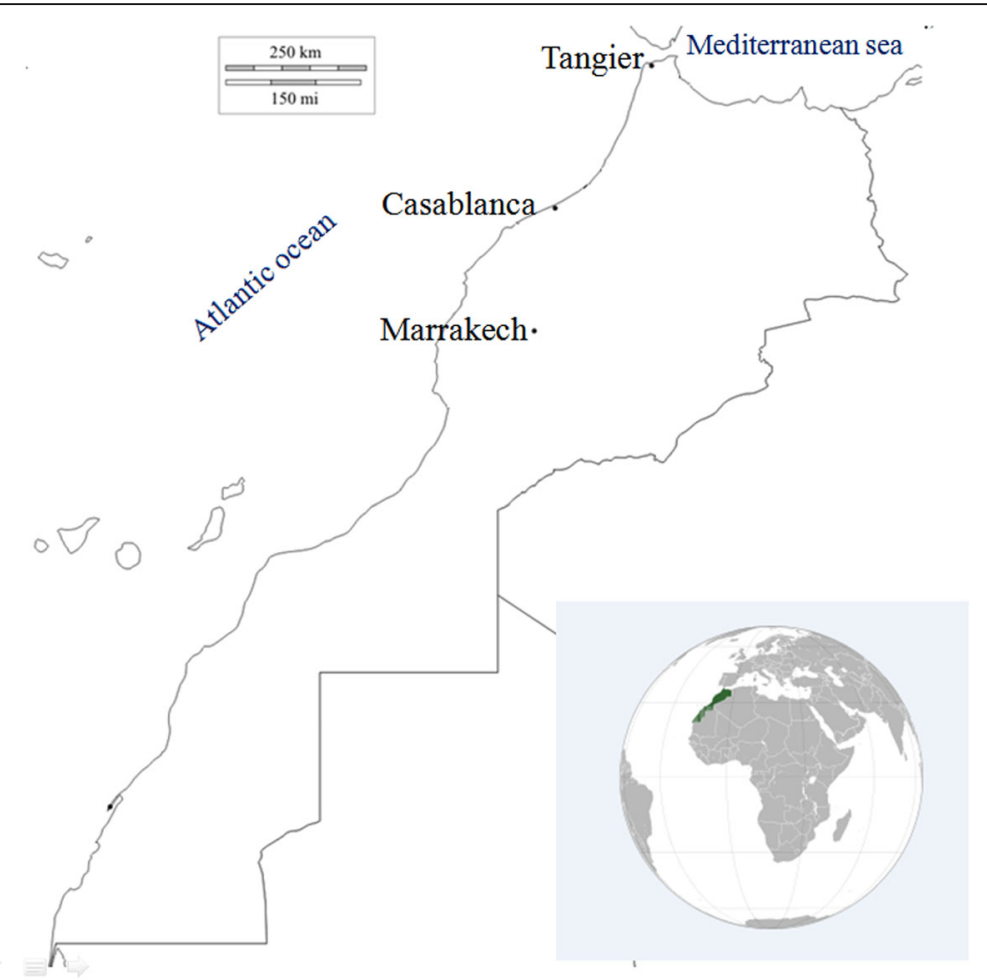

Fig 1 Localization of Culex pipiens collection sites in Morocco

The genotype frequencies were calculated by dividing the number of individuals with a given genotype by the total number of analyzed mosquitoes as follows: (i) homozygous wild type genotype frequency L1014/L1014, (ii) homozygous mutant genotype frequency, F1014/F1014, and (iii) heterozygote genotype frequency, L1014/F1014.

\section{Data analysis}

A categorical variable was compared by Fisher's exact test and Chi-square test. The association between the L1014F $k d r$ genotype frequencies and lambda-cyhalothrin resistance phenotypes was estimated by the odds ratio (OR) and its corresponding 95\% confidence interval (CI). Differences between groups were considered significant for $P$ values less than 0.05 . All tests were two sided.

\section{Results}

\section{Insecticide susceptibility and identification of Culex pipiens forms}

Twenty-four hours after exposure of $100 C x$. pipiens collected in Casablanca to lambda-cyhalothrin, $79 \%$ of exposed adults died. KDT50 and KDT90 were $27 \mathrm{~min}$ and $42 \mathrm{~min}$, respectively.

Insecticide-resistant and insecticide-susceptible adults after insecticide bioassays were tested by PCR to identify the Culex pipiens form. Most $C x$. pipiens resistant to lambda-cyhalothrin were pipiens $(43 \%, 9 /$ $21)$ and hybrids $(47.5 \%, 10 / 21)$ while molestus represented only $9.5 \%(2 / 21)$. Besides, Cx. pipiens susceptible to lambda-cyhalothrin were mainly pipiens $(36.5 \%, 29 / 79)$ and hybrids $(36.5 \%, 29 / 79)$ while $27 \%$ (21/79) were molestus.

\section{Kdr gene detection}

One hundred $C x$. pipiens adults collected in Casablanca were tested for the $k d r$ mutation. The frequency of genotypes was represented in Table 1.

All specimens of susceptible mosquitoes had 1014 L/ $1014 \mathrm{~L}$ genotype. Among the 21 resistant mosquitoes, 9 had $1014 \mathrm{~F} / 1014 \mathrm{~F}$ genotype, 5 had $1014 \mathrm{~F} / 1014 \mathrm{~L}$ genotype and 7 had $1014 \mathrm{~L} / 1014 \mathrm{~L}$ genotype (Table 2). Culex pipiens pipiens and hybrids showed a significant correlation between the $k d r$ resistant allele $1014 \mathrm{~F}$ and the resistant phenotype to lambda-cyhalothrin with OR $=76.3(P<0.0001)$ and OR $=172.1(P<0.0001)$, respectively (Table 2).

\section{Frequencies of Culex pipiens forms in three sites}

A total of 452 adults collected in Tangier, Casablanca and Marrakech were characterized by PCR and frequencies of different forms of $C x$. pipiens are presented in Table 3. Culex pipiens pipiens and $C x$. pipiens molestus and also their hybrids were found in urban and rural habitats. $49.9 \%$ 
Table 1 Frequencies of kdr mutation according to the phenotypic status (resistant/susceptible) of different forms of Cx. pipiens in Casablanca

\begin{tabular}{|c|c|c|c|c|c|c|}
\hline \multirow[b]{2}{*}{ Forms of Cx. pipiens } & \multirow[b]{2}{*}{ Phenotype } & \multirow[b]{2}{*}{$N(\%)$} & \multirow[b]{2}{*}{1014 L/1014 L n (\%) } & \multicolumn{3}{|l|}{ Genotype (\%) } \\
\hline & & & & 1014 L/1014 F n (\%) & 1014 F/1014 F n (\%) & Frequency of allele $1014 \mathrm{~F}(\%)$ \\
\hline \multirow[t]{2}{*}{ Cx. pipiens pipiens } & Susceptible & $29(76)$ & $29(100)$ & 0 & 0 & 0 \\
\hline & Resistant & $9(24)$ & $3(33)$ & $5(56)$ & $1(11)$ & 0.39 \\
\hline \multirow[t]{2}{*}{ Hybrid } & Susceptible & $29(74)$ & $29(100)$ & 0 & 0 & 0 \\
\hline & Resistant & $10(26)$ & $2(20)$ & $4(40)$ & $4(40)$ & 0.6 \\
\hline \multirow[t]{2}{*}{ Cx. pipiens molestus } & Sucseptible & $21(91)$ & $21(100)$ & 0 & 0 & 0 \\
\hline & Resistant & $2(9)$ & $2(100)$ & 0 & 0 & 0 \\
\hline
\end{tabular}

Abbreviation: $N$, number of individuals tested

of tested mosquitoes were pipiens form; $32.3 \%$ were hybrid and $20.8 \%$ were molestus form (Table 3 ).

Frequencies and distribution of $1014 \mathrm{~F}$ allele in three sites A total of $416 C x$. pipiens samples were examined. In Tangier, 143 individuals were tested for the $1014 \mathrm{~F}$ $k d r$ mutation: 185 samples in Casablanca, and 88 in Marrakech. The $k d r$ mutation was detected in the different forms of $C x$. pipiens in different sites of three cities in Morocco. The frequency of the 1014 F $k d r$ allele was similar between pipiens form and the hybrid form $\left(\chi^{2}=1.02, d f=1, P=0.312\right)$ while there was a significant difference of frequencies between pipiens form and molestus form $\left(\chi^{2}=57.11, d f=1, P<0.0001\right)$ and between molestus form and hybrid form $\left(\chi^{2}=\right.$ 44.23, $d f=1, P<0.0001)$. The frequencies were not significantly different between Tangier and Marrakech $\left(\chi^{2}=2.33, d f=1, P=0.127\right)$ (Table 4$)$.

\section{Discussion}

To the best of our knowledge, we report for the first time in Morocco the resistance status of different forms

Table 2 Correlation between the frequency of $1014 \mathrm{~F}$ allele and insecticide-resistance/-susceptible phenotypes to lambdacyalothrin

\begin{tabular}{|c|c|c|c|c|c|c|}
\hline \multirow{2}{*}{$\begin{array}{l}\text { Form of } \\
\text { Cx. pipiens }\end{array}$} & \multirow[t]{2}{*}{ Phenotype } & \multirow[t]{2}{*}{$N$} & \multicolumn{2}{|l|}{ Alleles } & \multirow[t]{2}{*}{ Odds ratio } & \multirow[t]{2}{*}{$P$-value } \\
\hline & & & 1014 F (R) & $1014 \mathrm{~L}(\mathrm{~S})$ & & \\
\hline \multirow{3}{*}{$\begin{array}{l}\text { Cx. pipiens } \\
\text { pipiens }\end{array}$} & Resistant & 9 & 7 & 11 & 76.3 & \multirow[t]{3}{*}{0.0001} \\
\hline & Susceptible & 29 & 0 & 58 & $4.06-1432$ & \\
\hline & Total & 38 & $9.2 \%$ & $90.8 \%$ & & \\
\hline \multirow[t]{3}{*}{ Hybrid } & Resistant & 10 & 12 & 8 & 172.1 & \multirow[t]{3}{*}{0.0001} \\
\hline & Susceptible & 29 & 0 & 58 & $9.3-3182$ & \\
\hline & Total & 39 & $14.4 \%$ & $85.6 \%$ & & \\
\hline \multirow{3}{*}{$\begin{array}{l}\text { Cx. pipiens } \\
\text { molestus }\end{array}$} & Resistant & 2 & 0 & 4 & \multirow[t]{3}{*}{9.0} & \multirow[t]{3}{*}{1} \\
\hline & Susceptible & 21 & 0 & 42 & & \\
\hline & Total & 23 & $0 \%$ & $100 \%$ & & \\
\hline
\end{tabular}

Abbreviation: $N$, number of individuals tested of $C x$. pipiens and also the frequency of the L1014F $k d r$ mutation in field populations. We found that $C x$. pipiens pipiens was more resistant than $C x$. pipiens molestus: 43 and $9.5 \%$, respectively. We also found that $C x$. pipiens pipiens and $C x$. pipiens molestus and their hybrids, cooccur in aboveground and underground breeding sites in urban, and rural habitats.

In Morocco, vector control programs use pyrethroids to treat adults as this insecticide family presents a high efficacy and low human toxicity [25, 26]. However, we showed that these insecticide treatments were correlated with high frequencies of 1014 F/1014 L genotype in field-collected mosquitoes. The L1014F $k d r$ mutation which affects the voltage gated sodium channel gene is one of the mechanisms of resistance against dichlorodiphenyltrichloroethane (DDT) and pyrethroids group of insecticides. Culex pipiens mosquitoes present a high resistance to pyrethroids, organophosphates and carbamates in many regions of Morocco with variable levels according to regions (data not published). Unexpectedly, we found that some mosquitoes presenting a resistant phenotype were homozygous for the kdr susceptible allele $1014 \mathrm{~L}$. This surprising result previously described by other teams [27] underlines that other resistance mechanisms can be involved. The presence or absence of $k d r$ mutation gives no indicationof the actual strength of resistance level. The presence of $k d r$ mutation alone cannot inform of the operational impact of the resistance. Even if the kdr mutation ispresent, contribution of other resistance mechanisms such as metabolic resistance could also play a crucial role in the impact of resistance. Resistance toinsecticides is an evolutionary phenomenon. The factors which condition its evolution depend at the same time on the biology of the insect, on the nature of the mechanisms involved and on the operational aspects of treatments. The study of the evolution resistance genes in vector populations is very important. It allows to assess the impact of the resistance on the efficacy of the vector control. In fact, the operational implications of resistance are not directly deductible only from the level of resistance measured in the laboratory. 
Table 3 Numbers and frequencies of Culex pipiens forms in Morocco (Tangier, Casablanca, Marrakech). Culex pipiens larvae were collected at different sites in Morocco, reared to adults and identified by PCR amplification of the flanking region of the CQ11 microsatellite. Frequencies of tested mosquitoes are in parentheses

\begin{tabular}{|c|c|c|c|c|c|c|c|c|c|}
\hline & \multicolumn{3}{|l|}{ Tangier } & \multicolumn{3}{|c|}{ Casablanca } & \multicolumn{3}{|c|}{ Marrakech } \\
\hline & Rural & Urban & Total & Rural & Urban & Total & Rural & Urban & Total \\
\hline & $n(\%)$ & $n(\%)$ & $n(\%)$ & $n(\%)$ & $n(\%)$ & $n(\%)$ & $n(\%)$ & $n(\%)$ & $n(\%)$ \\
\hline Cx. pipiens pipiens & $48(55)$ & $45(66)$ & $93(60)$ & $38(25)$ & $35(83)$ & $73(37)$ & $20(35)$ & $26(59)$ & $46(45.5)$ \\
\hline Hybrid & $37(43)$ & $22(32)$ & $59(38)$ & $36(23)$ & $5(12)$ & $41(21)$ & $28(49)$ & $18(41)$ & $46(45.5)$ \\
\hline Cx. pipiens molestus & $2(2)$ & $1(2)$ & $3(2)$ & $80(52)$ & $2(5)$ & $82(42)$ & $9(16)$ & $0(0)$ & $9(9)$ \\
\hline Total & 87 & 68 & 155 & 154 & 42 & 196 & 57 & 44 & 101 \\
\hline
\end{tabular}

Even if the resistance is present, it might not yet have an operational impact and this is why monitoring the resistance intensity in the population is important.

A total of 416 specimens were investigated for L1014F $k d r$ mutation. The L1014F mutation remains widespread in all three ecological regions. A higher proportion of heterozygous $1014 \mathrm{~L} / 1014 \mathrm{~F}$ genotype for $k d r$ mutation was found in Tangier and Marrakech, 66 and 60\%, respectively. It is known that the frequencies of $k d r$ heterozygous $1014 \mathrm{~L} / 1014 \mathrm{~F}$ genotypes were highly variable ranging from 14 to $80 \%$ depending on location sites [28-30]. Widespread use of pyrethroids within households may explain the high frequency of the $k d r$ mutation in urban areas. Moreover, the extensive use of pesticides in agriculture could also contribute to select the $k d r$ mutation in mosquito populations. Unlike the heterozygous 1014 L/1014 F genotypes, we found that the frequency of homozygous 1014 F/1014 F genotype was very low. The low proportion of homozygous 1014 F/1014 F Cx. pipiens can be consistent with a high fitness cost associated with the $k d r$ mutation. Additional studies are required to explore this hypothesis. The L1014F mutation has been reported at least in 39 arthropod species of which six are mosquitoes, three Culex spp. and three Anopheles spp. It has been reported in Cx. pipiens mosquitoes in at least 14 countries $[31,32]$.
It has been shown that the L1014F provides variable levels of protection to Type I or Type II pyrethroids [33]. The extensive use of pyrethroids for personal protection in urban environments, the recently introduced Ultra Low Volume (ULV) sprays against mosquitoes, as well as the long-term use of pyrethroids may have accelerated the selection of pyrethroid resistance mutations [34]. It has been shown that the L1014F mutation conferred a resistance to permethrin (Type I) in Cx. p. quinquefasciatus [35, 36] and to deltamethrin (Type II) in Cx. pipiens pallens [37].

\section{Conclusions}

Our work showed that $C x$. pipiens was resistant to lambda-cyhalothrin $0.05 \%$ and that the pipiens form was more resistant than the molestus form. Also, we described for the first time the distribution and the frequency of $k d r$ mutation in $C x$. pipiens complex from Morocco. These data provide suitable information for the design and implementation of successful resistance management strategies against this species, potential vector of arboviruses and to establish reliable diagnosis methods. Detection of specific pyrethroid resistance mutation can help to track and map the spread of resistance and also to assess the response of mosquito populations to future insecticide-based interventions.

Table 4 Frequencies of the $1014 \mathrm{~F} k d r$ allele

\begin{tabular}{|c|c|c|c|c|c|c|c|c|c|c|}
\hline \multirow[t]{2}{*}{ City } & \multirow[t]{2}{*}{ Site } & \multicolumn{3}{|c|}{ Cx. pipiens pipiens } & \multicolumn{3}{|c|}{ Hybrid } & \multicolumn{3}{|c|}{ Cx. pipiens molestus } \\
\hline & & $N$ & $\%$ & $95 \% \mathrm{Cl}$ & N & $\%$ & $95 \% \mathrm{Cl}$ & $\bar{N}$ & $\%$ & $95 \% \mathrm{Cl}$ \\
\hline \multirow[t]{3}{*}{ Tangier } & Rural & 45 & 0.44 & $0.34-0.54$ & 36 & 0.39 & $0.28-0.50$ & 2 & 1 & 1 \\
\hline & Urban & 38 & 0.24 & $0.14-0.34$ & 21 & 0.38 & $0.23-0.53$ & 1 & 0 & 0 \\
\hline & Total & 83 & 0.35 & $0.28-0.42$ & 57 & 0.38 & $0.29-0.47$ & 3 & 0.67 & $0.29-1.05$ \\
\hline \multirow[t]{3}{*}{ Casablanca } & Rural & 38 & 0.17 & $0.08-0.09$ & 36 & 0.25 & $0.15-0.35$ & 80 & 0 & 0 \\
\hline & Urban & 25 & 0.32 & $0.19-0.45$ & 4 & 0.25 & $0.00-0.25$ & 2 & 0.25 & $0.00-0.67$ \\
\hline & Total & 63 & 0.23 & $0.16-0.30$ & 40 & 0.35 & $0.25-0.45$ & 82 & 0.006 & $0.00-0.018$ \\
\hline \multirow[t]{4}{*}{ Marrakech } & Rural & 20 & 0.35 & $0.20-0.47$ & 28 & 0.21 & $0.10-0.32$ & 9 & 0.33 & $0.11-0.55$ \\
\hline & Urban & 18 & 0.25 & $0.11-0.39$ & 13 & 0.46 & $0.27-0.65$ & 0 & 0 & 0 \\
\hline & Total & 38 & 0.30 & $0.20-0.40$ & 41 & 0.29 & $0.19-0.39$ & 9 & 0.33 & $0.11-0.55$ \\
\hline & Total & 184 & 0.3 & $0.25-0.34$ & 138 & 0.32 & $0.26-0.37$ & 94 & 0.095 & $0.05-0.14$ \\
\hline
\end{tabular}




\section{Abbreviations}

AChE1: Acetylcholinesterase-1 enzyme; Cl: Confidence interval; CX: Culex; DDT: Dichlorodiphenyltrichloroethane; GABA: Gamma-aminobutyric acid; Kd: Knockdown; Kdr: Knockdown resistance; OP: Organophosphates; OR: Odds ratio; PCR: Polymerase chain reaction; PYR: Pyrethroids; RVFV: Rift valley fever virus; ULV: Ultra-low volume; WHO: World Health Organization; WNV: West Nile virus

\section{Acknowledgments}

We are grateful to Dr. Célestine-Nten Atyame from Pasteur Institute at Paris for her advice and her assistance to the development of $k d r$ mutation PCR. We thank also Dr. Sayeh Ezzikouri from Institut Pasteur of Morocco for helping us in statistical analysis.

\section{Funding}

This work was supported by Institut Pasteur of Morocco.

\section{Availability of data and materials}

All data generated or analysed during this study are included in the article.

\section{Author's contributions}

MB performed the experiments, analyzed the data and wrote the paper. FZT contributed in laboratory analysis. OC participated in the design of experiments. CF participates in analysis and interpretation of bioassay test results. ABF participated in the design of experiments and revised the draft. MS participated in the design of experiments, mosquito collections and revised the draft. All authors read and approved the final manuscript.

\section{Competing interests}

The authors declare that they have no competing interests.

\section{Consent for publication}

Not applicable.

\section{Ethics approval and consent to participate}

Not applicable.

\section{Author details}

'Institut Pasteur du Maroc, Laboratoire des Maladies Vectorielles, Place Louis Pasteur, Casablanca 20360, Morocco. ${ }^{2}$ Faculté des Sciences et Techniques de Mohammedia, Laboratoire de Virologie Microbiologie \& Qualité/ Eco-toxicologie \& Biodiversité, Université Hassan II de Casablanca, Casablanca, Morocco. ${ }^{3}$ Institut National d'Hygiène, Laboratoire d'Entomologie Médicale, Rabat, Morocco. ${ }^{4}$ Institut Pasteur, Department of Virology, Arboviruses and Insect Vectors, 25-28 rue du Docteur Roux, Paris 75724, France.

Received: 3 August 2016 Accepted: 6 December 2016 Published online: 16 December 2016

\section{References}

1. Chevalier V, Pepin M, Plee L, Lancelot R. Rift valley fever-a threat for Europe? Euro Surveill. 2010;15:19506.

2. Eisa M, Obeid H, El-Sawi A. Rift valley fever in the Sudan. I. Results on field investigations of the first epizootic in Kosti District, 1973. Bull Anim Health Prod Afr. 1977:24:343-7.

3. Woods CW, Karpati AM, Grein T, McCarthy N, Gaturuku P, Muchiri E, et al. An outbreak of Rift Valley fever in northeastern Kenya, 1997-98. Emerg Infect Dis. 2002;8:138-44.

4. Kahlon SS, Peters CJ, LeDuc J, Muchiri EM, Muiruri S, Njenga MK, et al. Severe Rift Valley fever may present with a characteristic clinical syndrome. Am J Trop Med Hyg. 2010;82:371-5.

5. Krida G, Diancourt L, Bouattour A, Rhim A, Chermiti B, Failloux A-B. Estimation du risque d'introduction du virus de la fièvre de la vallée du Rift en Tunisie par le moustique Culex pipiens. Bull Soc Pathol Exot. 2011;104:250-9.

6. Moutailler S, Krida G, Schaffner F, Vazeille M, Failloux A-B. Potential vectors of rift valley fever virus in the Mediterranean region. Vector Borne Zoonot Dis. 2008;8:749-54
7. Le Guenno B, Bougermouh A, Azzam T, Bouakaz R. West Nile: a deadly virus? Lancet. 1996:348:1315.

8. Triki H, Murri S, Le Guenno B, Bahri O, Hili K, Sidhom M, Dellagi K. Méningoencéphalite à arbovirus West Nile en Tunisie. Med Trop. 2001;61:487-90.

9. El Harrack M, Le Guenno B, Gounon P. Isolement du virus West Nile au Maroc. Virology. 1997;1:248-9.

10. Schuffenecker I, Peyrefitte CN, El Harrak M, Murri S, Leblond A, Zeller HG. West Nile virus in Morocco, 2003. Emerg Infect Dis. 2005;11:306-9.

11. Garbouj M, Bejaoui M, Aloui H, Ben Ghorba M. La maladie du Nil occidental. Bull Epidemiol. 2003;3:4-6.

12. Ben HT, Hammami S, Elghoul H, Ghram A. Detection of circulation of West Nile virus in equine in the north-west of Tunisia. B Soc Pathol Exot. 2011:104:266-71.

13. Amraoui F, Tijane M, Sarih M, Failloux A-B. Molecular evidence of Culex pipiens form molestus and hybrids pipiens/molestus in Morocco. North Africa Parasit Vectors. 2012;5:83-6.

14. Nauen R. Insecticide resistance in disease vectors of public health importance. Pest Manag Sci. 2007;63:628-33.

15. Whalon M, Mota-Sanchez D, Hollingworth R. Analysis of global pesticide resistance in arthropods. Global pesticide resistance in arthropods. Wallingford: CAB International; 2008. p. 5-31.

16. Lund AE. Pyrethroid modification of sodium channel: current concepts. Pestic Biochem Phys. 1984:22:161-8.

17. Vais H, Williamson MS, Devonshire AL, Usherwood PNR. The molecular interactions of pyrethroid insecticides with insect and mammalian sodium channels. Pest Manag Sci. 2001;57:877-88.

18. Soderlund D, Knipple D. The molecular biology of knockdown resistance to pyrethroid insecticides. Insect Biochem Molec. 2003;33:563-77.

19. Williamson MS, Martinez-Torres D, Hick CA, Devonshire AL. Identification of mutations in the housefly para-type sodium channel gene associated with knockdown resistance $(\mathrm{kdr})$ to pyrethroid insecticides. Mol Gen Genet. 1996;252:51-60.

20. Hollingworth R, Dong K. The biochemical and molecular genetic basis of resistance to pesticides in arthropods. Global pesticide resistance in arthropods. Wallingford: CAB International; 2008. p. 40-89.

21. El Ouali LA, El-Akhal F, El Amri N, Maniar S, Faraj C. State resistance of the mosquito Culex pipiens towards temephos central Morocco. Bull Soc Pathol Exot. 2014;107:194-8.

22. Brunhes J, Rhaim A, Geoffroy B, Angel G, Hervy JP. Les moustiques de I'Afrique méditerranéenne: logiciel d'identification et d'enseignement. Montpellier, France: IRD \& IPT, CD-Rom collection didactique, Éditions IRD; 2000.

23. Bahnck CM, Fonseca DM. Rapid assay to identify the two genetic forms of Culex (Culex) pipiens L. (Diptera: Culicidae) and hybrid populations. Am J Trop Med Hyg. 2006;75:251-5.

24. Martinez-Torres D, Chevillon C, Brun-Barale A, Bergé JB, Pasteur N, Pauron D. Voltage-dependent $\mathrm{Na}+$ channels in pyrethroid-resistant Culex pipiens $\mathrm{L}$ mosquitoes. Pestic Sci. 1999:55:1012-20.

25. Zaim M, Aitio A, Nakashima N. Safety of pyrethroid-treated mosquito nets. Med Vet Entomol. 2000:14:1-5.

26. WWF. Hazards and exposures associated with DDT and synthetic pyrethroids used for vector control. Washington: World Wildlife Fund; 1999.

27. Ibrahim SS, Manu YA, Tukur Z, Irving H, Wondji CS. High frequency of kdr L1014F is associated with pyrethroid resistance in Anopheles coluzzii in Sudan savannah of northern Nigeria. BMC Infect Dis. 2014;14:441-8.

28. Konaté L, Diallo M, Faye $\mathrm{O}$, Dia I. Patterns of insecticide resistance and knock down resistance $(\mathrm{kdr})$ in malaria vectors An. arabiensis, An. coluzzii and An. gambiae from sympatric areas in Senegal. Parasit Vectors. 2016;9:71-9.

29. Santolamazza F, Calzetta M, Etang J, Barrese E, Dia I, Caccone A, et al. Distribution of knock-down resistance mutations in Anopheles gambiae molecular forms in west and west-central Africa. Malaria J. 2008;7:74-81.

30. Gnanguenon V, Agossa FR, Badirou K, Govoetchan R, Anagonou R, OkeAgbo F, et al. Malaria vectors resistance to insecticides in Benin: current trends and mechanisms involved. Parasit Vectors. 2015;8:223-36.

31. Dong K, Du Y, Rinkevich F, Nomura Y, Xu P, Wang L, et al. Molecular biology of insect sodium channels and pyrethroid resistance. Insect Biochem Molec 2014;50:1-17.

32. Scott JG, Yoshimizu MH, Kasai S. Pyrethroid resistance in Culex pipiens mosquitoes. Pest Manag Sci. 2015:120:68-76.

33. Burton MJ, Mellor IR, Duce IR, Davies TE, Field LM, Williamson MS Differential resistance of insect sodium channels with kdr mutations to deltamethrin, permethrin and DDT. Insect Biochem Molec. 2011;41:723-32. 
34. Kioulos I, Kampouraki A, Morou E, Skavdis G, Vontas J. Insecticide resistance status in the major West Nile virus vector Culex pipiens from Greece. Pest Manag Sci. 2014;70:623-7.

35. Xu Q, Liu H, Zhang L, Liu N. Resistance in the mosquito, Culex quinquefasciatus, and possible mechanisms for resistance. Pest Managt Sci. 2005:61:1096-102.

36. Xu Q, Tian L, Zhang L, Liu N. Sodium channel genes and their differential genotypes at the L-to-F kdr locus in the mosquito Culex quinquefasciatus. Biochem Biophys Res Commun. 2011:407:645-9.

37. Chen L, Zhong D, Zhang D, Shi L, Zhou G, Gong M, et al. Molecular ecology of pyrethroid knockdown resistance in Culex pipiens pallens mosquitoes. Plos One. 2010;5:e11681

Submit your next manuscript to BioMed Central and we will help you at every step:

- We accept pre-submission inquiries

- Our selector tool helps you to find the most relevant journal

- We provide round the clock customer support

- Convenient online submission

- Thorough peer review

- Inclusion in PubMed and all major indexing services

- Maximum visibility for your research

Submit your manuscript at www.biomedcentral.com/submit
) Biomed Central 